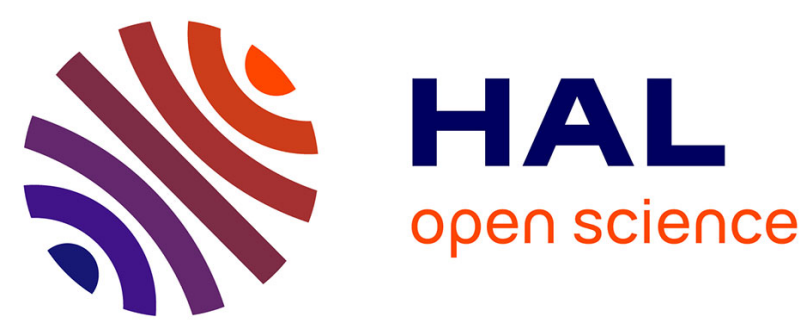

\title{
The accuracy of scat identification in distribution surveys: American mink, in the northern highlands of Scotland
}

Lauren A. Harrington, Andrew L. Harrington, Joelene Hughes, David Stirling, David W. Macdonald

\section{To cite this version:}

Lauren A. Harrington, Andrew L. Harrington, Joelene Hughes, David Stirling, David W. Macdonald. The accuracy of scat identification in distribution surveys: American mink, , in the northern highlands of Scotland. European Journal of Wildlife Research, 2009, 56 (3), pp.377-384. 10.1007/s10344-0090328-6 . hal-00535257

\section{HAL Id: hal-00535257 \\ https://hal.science/hal-00535257}

Submitted on 11 Nov 2010

HAL is a multi-disciplinary open access archive for the deposit and dissemination of scientific research documents, whether they are published or not. The documents may come from teaching and research institutions in France or abroad, or from public or private research centers.
L'archive ouverte pluridisciplinaire HAL, est destinée au dépôt et à la diffusion de documents scientifiques de niveau recherche, publiés ou non, émanant des établissements d'enseignement et de recherche français ou étrangers, des laboratoires publics ou privés. 


\title{
The accuracy of scat identification in distribution surveys: American mink, Neovison vison, in the northern highlands of Scotland
}

\author{
Lauren A. Harrington • Andrew L. Harrington • \\ Joelene Hughes • David Stirling • David W. Macdonald
}

Received: 15 July 2009 /Revised: 17 August 2009 /Accepted: 17 September 2009/Published online: 14 October 2009

(C) Springer-Verlag 2009

\begin{abstract}
Distribution data for elusive species are often based on detection of field signs rather than of the animal itself. However, identifying field signs can be problematic. We present here the results of a survey for American mink, Neovison vison, in the northern highlands of Scotland to demonstrate the importance of verifying field sign identification. Three experienced surveyors located scats, which they identified as mink scats, at seven of 147 sites surveyed and "possible" mink scats at a further 50 sites. Mitochondrial DNA was successfully extracted from 45 of $75(60 \%)$ scats, collected from 31 of the 57 "positive" sites; sequencing of amplified DNA fragments showed that none of these scats was actually of mink origin. We consider the implications of erroneous survey data and the potential waste of resources and misdirection of conservation/ management actions. We discuss potential methods that may be useful to verify field sign identification, including the use of DNA analysis, and stress that verification is crucial to ensure rigorous and reliable survey data.
\end{abstract}

Keywords DNA analysis · Genetic identification .

Mustelids $\cdot$ Neovison $\cdot$ Sign surveys $\cdot$ Scats

Communicated by W. Lutz

L. A. Harrington $(\bowtie) \cdot$ A. L. Harrington · J. Hughes •

D. W. Macdonald

Wildlife Conservation Research Unit, Department of Zoology, University of Oxford,

Tubney House, Abingdon Road, Tubney,

OX13 5QL Oxford, UK

e-mail: lauren.harrington@zoo.ox.ac.uk

D. Stirling

Department of Haematology, Royal Infirmary of Edinburgh,

Little France Crescent,

EH16 4SA Edinburgh, UK

\section{Introduction}

Accurate knowledge of species distribution is vitally important for wildlife conservation, protection, and management. However, recorded distributions can reflect the distribution of recorders rather than of the species. Furthermore, for many elusive species, it is often possible to survey only for indirect indices (such as hairs, scats (faeces), or footprints; Gibbs 2000), but these depend on identification of field signs that may be uncertain or inaccurate. Basing management strategies on data subject to these inaccuracies may diminish their efficacy and prove both logistically and financially costly. It is possible to improve the accuracy of distribution data through systematic surveys and now, due to developments in genetic analysis techniques, through DNA identification of field signs (e.g. Darling and Blum 2007). This study demonstrates the importance of using DNA analysis to verify field sign identification when surveying for an invasive mustelid species in the Scottish Highlands.

American mink Neovison vison (formerly Mustela vison; Wilson and Reeder 2005) were introduced to Britain in the 1930s for fur farming (reviewed in Macdonald and Harrington 2003). As a result of escapees, mink are present as feral populations throughout most of the country, with the apparent exception of the northernmost highland region of Scotland (National Biodiversity Network: data.nbn.org. uk). However, prior to this study, it was not clear whether it was mink or recorders that were absent from the north highlands.

Traditionally, there have been no species-specific surveys for American mink in the UK, rather, mink signs are recorded as part of national surveys for otters Lutra lutra (e.g. Strachan 2007) and water voles Arvicola terrestris (e.g. Jefferies 2003). Recent otter surveys (Green and Green 
1997; Strachan 2007) reported a low incidence of mink signs in the north of Scotland, but because survey protocol dictated that the search of a particular site was terminated when otter sign was located, it is possible that mink sign went unobserved (this is particularly likely in areas such as the north of Scotland where otters and their signs are at relatively high density; Kruuk 2006; Strachan 2007).

The north of Scotland, with its associated islets and offshore islands, provides habitats for several bird species of conservation concern (e.g. common gull Larus canus, black grouse Tetrao tetrix, RSPB 2002). The northern highlands also host some of the last remaining extensive populations of water voles in the UK (e.g. Fraser et al. 2005). Mink predation has had devastating impacts on the breeding success of seabirds on the west coast of Scotland (Craik 1997) and is largely responsible for the near extinction of the water vole in England (Strachan et al. 1998; Jefferies 2003). There are, therefore, important conservation reasons for controlling American mink in this region.

To inform regional management plans, we designed and carried out a survey to assess the distribution of American mink in the northern highlands of Scotland. We used sign survey methods (cf. Bonesi and Macdonald 2004) as this is the most practical technique for large-scale, one-off surveys. Standard sign survey methods for mink involve searches for both footprints and scats along riverbanks. Finding footprints is dependent on substrate (Bonesi and Macdonald 2004), and therefore, over all areas, scats tend to be the most frequently found field sign. Given the presence of otters, pine martens Martes martes, polecats Mustela putorius, and feral ferrets Mustela furo in the region and the potential for misidentifying scats, we used DNA analysis of scats to verify the species of origin (see Hansen and Jacobsen 1999).

One limitation of scat surveys is that the distribution and abundance of scats depend not only on the abundance of the animal but also on its marking behaviour. In mink (as in many other animals), marking behaviour is poorly understood and may be affected by the presence of competitors (Harrington 2007; Garcia et al. 2009). To validate our sign survey results, we used tracking rafts (described in Reynolds et al. 2004) as an additional, independent method, at a subsample of survey sites. Tracking rafts comprise a tracking plate beneath a tunnel floating at the rivers' edge and therefore, depend only on the mink passing through the raft tunnel.

\section{Methods}

Survey area

We surveyed the coastline and inland area of the northern highlands of Scotland, north of Ullapool $\left(57^{\circ} 56^{\prime} \mathrm{N}, 5^{\circ} 11^{\prime} \mathrm{W}\right)$ on the west coast, and the Dornoch Firth $\left(57^{\circ} 52^{\prime} \mathrm{N}, 4^{\circ} 21^{\prime} \mathrm{W}\right)$ in the east (Fig. 1), between March and June 2008.

The coastline differs between the west and the east, being predominantly rocky on the west coast, characterised by high mountainous ground and moorland, and sandy on the east, where the land use is largely agricultural. Inland areas are predominantly high mountainous ground, alpine heath, open heather moorland or rough grassland, and blanket bog, rising to $>1,000 \mathrm{~m}$ above sea level, interspersed with numerous streams, rivers, freshwater lochs (lakes), and lochans (small lakes). Sea lochs are also found on the coast. Rivers and streams are typically fast-flowing, oligotrophic, and prone to spate after heavy rainfall.

Otters are present throughout the northern highlands (Strachan 2007); foxes Vulpes vulpes, stoats Mustela erminea, and pine martens are also present (National Biodiversity network: data.nbn.org.uk). Polecats and feral ferrets are patchily distributed and thought to be at low density (Birks 2008).

Temperatures in the area vary between $<16-19^{\circ} \mathrm{C}$ (mean daily maximum in summer) to $2^{\circ} \mathrm{C}$ to $-1^{\circ} \mathrm{C}$ (mean daily minimum in winter), with a mean of $<40$ to $>100$ days of snow per year, on the coast and the highlands, respectively, between November and April. Average annual rainfall is $1,700 \mathrm{~mm}$ in the west and $700 \mathrm{~mm}$ in the east (www. metoffice.gov.uk/climate/uk/ns/).

\section{Survey strategy and methods}

Surveyors Surveys were carried out by ALH and two other experienced surveyors. All surveyors had several years experience carrying out mink (and otter) surveys in a variety of habitats, in the UK, Estonia, and Patagonia. A trainee accompanied the surveyors but did not identify field signs.

Scat surveys We surveyed 2-km stretches of waterway (coastline, river, or lake edge) at each survey site. We chose 2-km survey sites (rather than the standard $600 \mathrm{~m}$ used in national surveys, e.g. Strachan 2007), because this corresponds with the average home range size of a mink (Dunstone 1993; Yamaguchi and Macdonald 2003; Harrington and Macdonald 2008), thus, increasing the chance of locating signs if mink are present. One survey site was selected per stretch of $8 \times 1-\mathrm{km}$ consecutive national grid squares. The grid squares were measured around the coastline for the coastal survey sites and along roads for the inland survey sites (in the latter case, the nearest waterway to the selected point on the road was surveyed). Roads in the region tend to follow river valleys and therefore, provide relatively easy access to the main rivers and their tributaries for the majority of the inland area. Survey sites were not located systematically but were 
Fig. 1 Mink survey sites. The map shows sign survey sites (a) and tracking raft locations (b). Each sign survey site (shown by a circle) was a $2-\mathrm{km}$ stretch of waterway and searched for footprints and scats deemed to belong to American mink. Rafts (shown by a square) were left in situ for approximately 6 weeks and checked for tracks at least twice. Surveys were carried out between March and May 2008 a

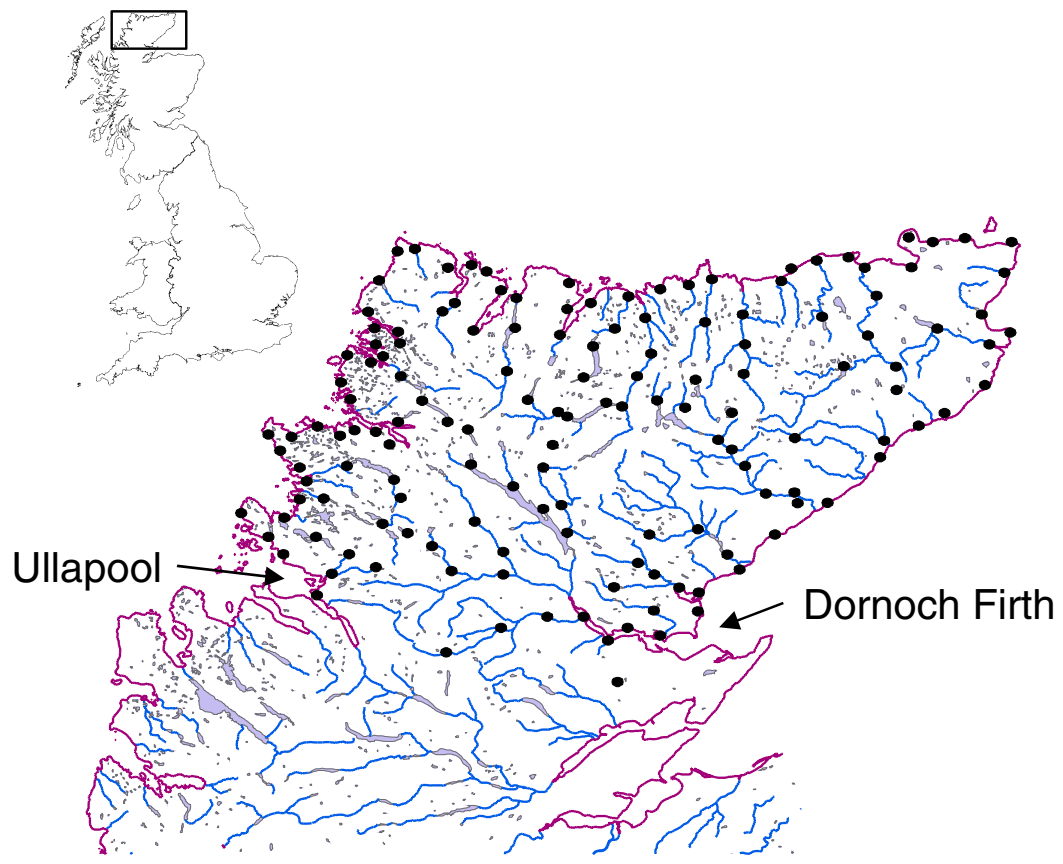

b

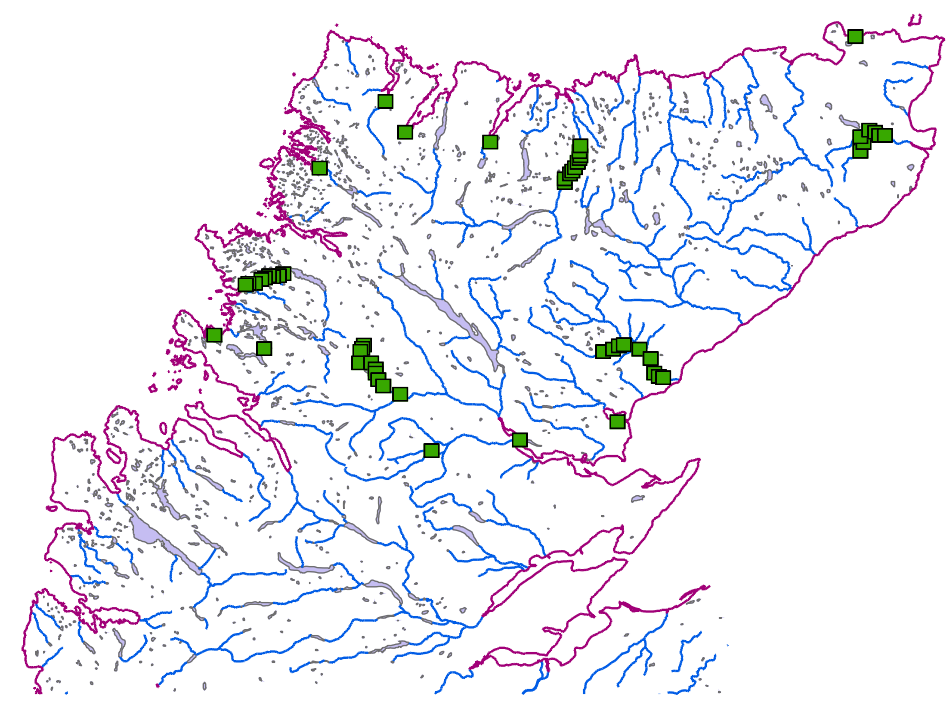

selected to target sites deemed to be optimal for detecting mink signs (i.e. at the confluence of streams and rivers, or for coastal sites, at river inlets) within each stretch of $8 \times 1-\mathrm{km}$ squares. On the coast, we did not restrict survey sites to a linear stretch of coastline because mink are likely to use a variety of aquatic habitats in coastal regions, such as freshwater lochs, ponds, and nearby streams and rivers (Dunstone 1993). Therefore, coastal surveys covered a $2-\mathrm{km}$ stretch of waterway that occurred within a $1-\mathrm{km}$ band from the coastline from the designated survey point. Wherever possible, we covered a variety of habitat types in any one 2-km survey site. The sample strategy allowed the necessary flexibility in site selection to target survey efforts in such a way as to increase the probability of detecting signs (if they were present), whilst also maintaining independence among sites (one mink is unlikely to be detected at two sites). To ensure even and complete coverage, we divided the northern highland inland area into $10-\mathrm{km}$ squares and checked that, using this sampling strategy, at least one survey site fell within each $10-\mathrm{km}$ square (this was the case for approximately $75 \%$ of $10-\mathrm{km}$ squares within the general survey area). We then designated additional survey sites along the main waterway in each of the $10-\mathrm{km}$ squares that did not already contain a survey site using the "road" method. Survey site locations are shown in Fig. 1a. 
Survey sites were searched for mink signs (scats and tracks) using standard methods (e.g. Strachan 1995). Footprints were identified as belonging to mustelids by their characteristic shape and track pattern (Sidorovich 1999) and were distinguished from otter tracks on the basis of size (Strachan 1995). Mink scats were identified in the field on the basis of size, shape, and smell (Dunstone 1993; Strachan 1995). Because we expected mink signs to be at low density and because we were using DNA analysis to verify field results, we adopted a conservative approach and recorded all signs detected that were similar in size and shape to those of mink. On this basis, each site was provisionally classified as either positive or negative for the presence of mink sign and the type of sign found (footprint or scats), and confidence of identification was recorded.

Raft surveys A total of 55 rafts was deployed at approximately $1 \mathrm{~km}$ intervals (following methods in Harrington et al. 2008a) on six rivers (seven to ten rafts per river) and at nine additional sites in coastal regions (Fig. 1b). Full descriptions of the rafts and operation methods are given in Reynolds et al. (2004) and in Harrington et al. (2008a). Rafts were installed towards the end of the survey period at the end of April, they were checked for tracks 4 weeks later at the end of May, and again, after a further 2 weeks, in mid-June. Mink footprints were distinguished from otter footprints on the basis of size (Strachan 1995) and from polecat or ferret footprints using methods in Harrington et al. (2008b).

\section{Genetic identification of mink scats}

All scats found that were provisionally identified as being of mink origin were collected, stored in $96 \%$ alcohol, and sent to the Department of Haematology, Royal Infirmary of Edinburgh for DNA analysis.

DNA was extracted from scat material using the QIAamp DNA stool mini kit (QIAGEN, Crawley, West Sussex, UK). Aliquots of the samples $(\sim 10 \%$ of solid material) were first centrifuged at $1200 \times g$, and the alcohol removed, before the addition of sterile distilled water and subsequent processing as per the kit procedure. Where polymerase chain reaction (PCR) amplification subsequently failed, the entire remaining sample was processed. For this large-scale extraction, the sample was first centrifuged and resuspended in water, before being extracted with chloroform, and precipitated with 0.1 volume $3 \mathrm{M} \mathrm{NaOAc}$ and two volumes of ethanol. The subsequent pellet was resuspended in $200 \mu \mathrm{l}$ sterile distilled water and extracted as per the kit protocol.

Extracted DNA was amplified with consensus PCR primers capable of amplifying a portion of the mitochon- drial cytochrome $\mathrm{b}$ gene from stoat, weasel, polecat, mink, pine marten, otter, and fox (Cytochrome-b-ups-TRG GAG ACC CAG ACA A; Cytochrome-b-dow-ATV CYH CGT TGT TTT GA). These primers were designed on an alignment of the cytochrome $b$ genes from each of the species of interest and were checked to confirm amplification of the appropriate fragment from a sample of genomic DNA from each species.

The resultant amplified DNA fragments were sequenced using the reverse oligo as sequencing primer, using $\mathrm{ABI}$ "Big Dye" dye terminator chemistry and an ABI 3130 instrument (Applied Biosystems, Foster City, CA, USA). Amplified DNA fragment sequences were subjected to a "BLAST" search (http://www.ncbi.nlm.nih.gov) to determine the correct species of origin and were, additionally, checked against our own "reference" sequences, obtained from DNA of known origin.

\section{Results}

A total of 147 sites was surveyed (71 coastal sites and 76 inland sites). We found signs confidently deemed to belong to mink in seven $(4.8 \%)$ survey sites and "possible mink" signs in a further $50(34 \%)$ survey sites. All but one of the signs found were scats, only one track was found.

None of the 55 rafts registered tracks at the first check at the end of May. A single raft in June had a single incomplete track that appeared to belong to a mustelid and to be of the correct size for mink. The incomplete nature of the track, however, rendered identification uncertain.

Scats from 46 of the 57 sites provisionally recorded as positive, or "possibly" positive, for mink, were sent to the lab for DNA analysis ( $n=75$ scats in total). DNA was successfully extracted and amplified from 45 of the 75 (60\%) scat samples, covering 31 of the 46 sites (67\%). None of these scats was identified as originating from mink. Most of the scats were of pine marten $(47 \%)$ or fox $(41 \%)$ origin, others were otter $(6 \%)$, polecat $(3 \%)$, or stoat (3\%.).

\section{Discussion}

DNA analysis of scats detected in this survey, coupled with the absence of tracks on rafts, suggest that it is highly unlikely that there is a large, resident population of American mink in the northern highlands of Scotland. If there are mink in this region, their presence is most likely restricted to lone, transient individuals.

In the absence of DNA analysis, however, we could have concluded from our survey results that at least seven (4.8\%) sites were positive for mink, and possibly up to $50(34 \%$; 
depending on the level of conservatism), and suggested that mink were present (albeit at relatively low densities) and widespread throughout the northern highlands. If this information had been used to inform future management plans in the region, it could have led to costly, time-consuming, and fruitless eradication programmes. In contrast, the DNA results indicate that there are very few, if any, mink in the highlands and efforts can, therefore, focus on preventing and understanding the spread of mink populations from the south. Our DNA results show that the ability of even experienced surveyors to accurately identify mink scats, in the presence of other mustelids or small carnivores, is questionable. Two of the three surveyors in this study had previously, over several years, carried out numerous mink surveys in southern England where pine martens are absent, polecats, at the time of the survey, occurred at low density, and the predominant scat-type found along the riverbank were otter spraints - in that study, and in stark contrast to this study, $100 \%$ of a random sample of 61 "mink" scats were confirmed, using DNA analysis, to have been correctly identified in the field as mink scats (Harrington et al. 2008a). The difference, in this case, appears to be at least partly due to the presence of pine martens. Foxes were present in both areas, and it is unclear why fox scats (which are normally much larger than mink scats; Strachan 1995) would be misidentified as mink scats in northern Scotland but not in southern England, but perhaps the habitat differs in such a way that foxes do not use the riverbanks in southern England in the same way that they do in Scotland (several of the fox scats were also found along the coast) or perhaps diet affected their appearance. The survey was carried out in the spring, and so, it is also possible that the fox scats encountered were from young foxes and thus, were smaller and similar in size to typical mink scats.

Another striking difference between the two studies (this and Harrington et al. 2008a) was the success rate for DNA extraction and amplification. In the Scottish study, only $60 \%$ of the scats yielded DNA from which the cytochrome $b$ gene could be successfully amplified. There are several possible explanations for this difference that could be ruled out. Firstly, the Scottish study used a different set of primers from the previous study to allow for the amplification of fox along with the previous target species, however, these primers still amplified all the species targets efficiently, and samples which failed to amplify with the new primers were reanalysed with the primers used in the previous study and still failed. Secondly, efficiency of extraction may have contributed to the difference as there is no established quality control material for this DNA extraction method from scats. Yet, a proportion still failed even though each "difficult" DNA was repeated using an altered protocol. Finally, it is possible that sequence variation exists within the cytochrome $\mathrm{b}$ gene that results in a portion of the population not being amplified. However, this would appear to be unlikely as two distinct sets of primers were used, and this gene is generally well conserved within species. The most likely explanation for the failures is degraded DNA (due to samples that were not fresh, or that had been subject to adverse weather conditions, cf. Kalz et al. [2006]). Other studies have found similar success rates (e.g. Davison et al. [2002] were only able to successfully extract and amplify DNA from $53 \%$ of pine marten scats).

Davison et al. (2002) tested the reliability of experienced naturalists in identifying pine marten scats and found that, at normal densities, up to $30 \%$ of scats collected were incorrectly identified. In low density areas, errors were even higher, with $97 \%$ of 30 scats identified as being of pine marten origin actually belonging to fox or polecat. For pine martens, as we found for mink in this study, scat surveys are unreliable without genetic verification (Birks et al. 2004). The problem is not limited to mustelids: in recent sign surveys for snow leopards, up to $54 \%$ of scats identified as putative snow leopard origin were found to be from red fox (Janečka et al. 2008). Similar errors have been found when attempting to identify canid scats (e.g. Reed et al. 2004; see also Long et al. 2007) and macropod scats (Bukinski and McArthur 2000) on the basis of size and morphological characteristics. Observer bias and inaccurate identification of field signs are also problematic for snow-tracking surveys, and McKelvey et al. (2006) recommend that DNA analysis of scats and hairs found alongside snow tracks are used to verify identification. Prugh and Ritland (2005), in contrast, found surveyors to be highly accurate in identifying coyote scats in winter when identification could be further substantiated by the presence of tracks in the snow. Indigenous people were also able to identify a number of felid and canid scats in forests in Paraguay (although they were unable to distinguish between the three species of small spotted cat-margay, Leopardus wiedii, oncilla, Leopardus tigrinus, and Geoffrey's cat, Leopardus geoffreyi-Zuercher et al. 2003). Examples of high success rates in identifying field signs do not, however, negate that fact that identification of scats in the field can be (and often is) unreliable. We recommend that all studies reliant on scats incorporate molecular testing to verify the accuracy of identification during the pilot stage of the project, or on a subsample of scats, and that the need for further molecular work is established on a case-by-case basis. The implications of potentially inaccurate field sign survey results, when identification is not verified, may be significant and may lead to flawed scientific conclusions and misdirection of conservation and/or management efforts, with consequential waste of time and resources.

A database search of research involving mammal surveys published in the last 5 years in five of the major conservation/management journals (Biological Conserva- 
tion, Animal Conservation, Journal of Wildlife Management, Wildlife Society Bulletin, European Journal of Wildlife Research) revealed a total of 50 studies (see Appendix 1 for a list of papers considered). Of these, 34 $(68 \%)$ were based on sign surveys but only $11(22 \%)$ of these included genetic analysis to verify species identification. Genetic verification of a sign may not always be necessary, for example, if there are no other similar species in the region, however, it is an underutilised, powerful tool for increasing the accuracy of surveys that currently rely solely on surveyor experience.

The problem with DNA analysis is the cost, which, at between 15 and 50 GBP ( US \$25-82, €18-59) per sample, may be prohibitive. The approach we have taken has been to amplify a portion of a conserved mitochondrial gene and sequence it. This allows one set of reactions to be used to identify all target species, rather than having to generate distinct primer sets or probes for each species (as would be the case for real-time (RT) PCR). Although sequencing is regarded as the "gold standard" for DNA analysis, where greater numbers of samples are required to be analysed, RTPCR would offer a significant cost advantage. DNA would have to be extracted for both procedures, but costs for RTPCR could be as low as a 2-3 GBP per sample for studies with several hundreds of samples. RTPCR instruments cost a few thousand pounds (GBP) compared to $50,000-100,000$ GBP for sequencing instruments, and their operation is generally simpler. However, great care has to be taken over both the design and validation of the RTPCR system and the analysis of the data, as the differing templates can yield very similar results. Further, the costs of verifying survey results must be balanced against the cost of the survey itself (which are usually considerable: this survey required $\sim 70$ man-days to complete, plus the fuel and associated transport costs required to drive an average of $100 \mathrm{~km} /$ day) and the risk that this cost may be wasted if identification of field signs is not verified. The downstream costs of action based on incorrect data could obviously be immense.

Other potential methods for verifying the species identification of field signs include thin-layer chromatography of faecal bile acids (e.g. Major et al. 1980; Johnson et al. 1984; Fernandez et al. 1997), chemical characterisation (by gas chromatography) of vapour emissions (volatile organic components) of scats (Burnham et al. 2008), microscopic analysis of groomed hair in scats (e.g. Harrington et al. [2008a] found polecat hairs in putative mink scats indicating that they were, in fact, polecat scats), and trained sniffer dogs (e.g. Smith et al. 2003; Wasser et al. 2004). The use of dogs, in particular, may be used for prescreening (as well as for efficient scat location) and to reduce the number of samples (and hence cost) for DNA analysis. The disadvantage of the use of bile acids is that they are soluble in water and therefore, exposure to rain may render scats unidentifiable by this method. Gas chromatography of vapour emissions is generally considered to be better and potentially (albeit expensive) portable technology exists that might allow field analysis of samples (zNose ${ }^{\circledR}$, Electonic Sensor Technology: www.estcal.com), although it has not yet been adapted for this purpose. Secondary methods that provide verified records of a species presence (e.g. camera traps, Zielinski and Kucera 1995) may also be useful.

\section{Conclusions}

Our results suggest that there are very few, if any, American mink in the northern highlands of Scotland. This, in itself, raises interesting ecological questions but these are beyond the scope of this paper. Most importantly, our results have serious implications for any study that is based on collection of scats where scat identification may be uncertain. This study demonstrates that, in systems with multiple similar, sympatric species, field signs (in particular, scats) may easily be wrongly identified and may not be a reliable indicator of specific species presence. We stress that secondary supplemental methods (DNA analysis and others) that are available to verify species identification are essential in any such survey to ensure reliable data collection.

Acknowledgements We are grateful to Andy Rothwell, Laura Fasola, and Rannveig Magnusdottir for help in the field, to Alastair Driver for encouraging us to undertake this survey, and Scottish Natural Heritage, the Environment Agency, the People's Trust for Endangered Species, and the European Nature Trust for funding. We thank Stephen Ellwood and Johnny Birks for comments on an earlier version of this manuscript.

\section{Appendix 1}

Ashton KG, Burke RL (2007) Long-term retention of a relocated population of gopher tortoises. J Wildl Manage 71:783-787

Ball LC, Doherty PF et al (2005) An occupancy modeling approach to evaluating a Palm Springs ground squirrel habitat model. J Wildl Manage 69:894-904

Banks MA, Ellis ER et al (2007) Global population size of a critically endangered lemur, Perrier's sifaka. Anim Conserv 10:254-262

Barlow ACD, Ahmed MIU et al (2008) Linking monitoring and intervention for improved management of tigers in the Sundarbans of Bangladesh. Biol Conserv 141:2032-2040

Baxter RJ, Flinders JT et al (2008) Survival, movements, and reproduction of translocated greater sage-grouse in Strawberry Valley, Utah. J Wildl Manage 72:179-186

Bonesi L, Strachan R et al (2006) Why are there fewer signs of mink in England? Considering multiple hypotheses. Biol Conserv 130:268-277

Choate DM, Wolfe ML et al (2006) Evaluation of cougar population estimators in Utah. Wildl Soc Bull 34:782-799 
Ciani AC, Palentini L et al (2005) Population decline of Macaca sylvanus in the Middle Atlas of Morocco. Biol Conserv 121:635641

Clark JD, van Manen FT et al (2005) Bait stations, hard mast, and black bear population growth in Great Smoky Mountains National Park. J Wildl Manage 69:1633-1640

de Azevedo FCC, Murray DL (2007) Spatial organization and food habits of jaguars (Panthera onca) in a floodplain forest. Biol Conserv 137:391-402

Duchamp JE, Yates M et al (2006) Estimating probabilities of detection for bat echolocation calls: an application of the double-observer method. Wildl Soc Bull 34:408-412

Gallant D, Vasseur L et al (2007) Unveiling the limitations of scat surveys to monitor social species: a case study on river otters. J Wildl Manage 71:258-265

Garel M, Cugnasse JM et al (2005) Monitoring the abundance of mouflon in south France. Eur J Wildl Res 51:69-76

Gervasi V, Brunberg S et al (2006) An individual-based method to measure animal activity levels: a test on brown bears. Wildl Soc Bull 34:1314-1319

Gompper ME, Kays RW et al (2006) A comparison of noninvasive techniques to survey carnivore communities in northeastern North America. Wildl Soc Bull 34:1142-1151

Griffin SC, Taper ML et al (2008) The case of the missing marmots: are metapopulation dynamics or range-wide declines responsible? Biol Conserv 141:1293-1309

Harden CD, Woolf A et al (2005) Influence of exurban development on hunting opportunity, hunter distribution, and harvest efficiency of white-tailed deer. Wildl Soc Bull 33:233-242

Harrison RL (2006) A comparison of survey methods for detecting bobcats. Wildl Soc Bull 34:548-552

Hebblewhite M, Merrill EH et al (2006) Is the migratory behaviour of montane elk herds in peril? The case of Alberta's Ya Ha Tinda elk herd. Wildl Soc Bull 34:1280-1294

Hedges S, Tyson MJ et al (2005) Distribution, status, and conservation needs of Asian elephants (Elephas maximus) in Lampung Province, Sumatra, Indonesia. Biol Conserv 124:35-48

Homyack JA, Harrison DJ et al (2007) Effects of precommercial thinning on snowshoe hares in Maine. J Wildl Manage 71:4 13

Johnson AE, Knott CD et al (2005) A survey of the orangutan (Pongo pygmaeus wurmbii) population in and around Gunung Palung National Park, West Kalimantan, Indonesia based on nest counts. Biol Conserv 121:495-507

Kerley LL, Salkina GP (2007) Using scent-matching dogs to identify individual Amur tigers from scats. J Wildl Manage 71:1349-1356

Killengreen ST, Ims RA et al (2007) Structural characteristics of a low Arctic tundra ecosystem and the retreat of the Arctic fox. Biol Conserv 135:459-472

Koehler GM, Maletzke BT et al (2008) Habitat fragmentation and the persistence of lynx populations in Washington state. J Wildl Manage 72:1518-1524

Leuteritz TEJ, Lamb $\mathrm{T}$ et al (2005) Distribution, status, and conservation of radiated tortoises (Geochelone radiata) in Madagascar. Biol Conserv 124:451-461

Long RA, Donovan TM et al (2007b) Comparing scat detection dogs, cameras, and hair snares for surveying carnivores. J Wildl Manage 71:2018-2025

Magoun AJ, Ray JC et al (2007) Modeling wolverine occurrence using aerial surveys of tracks in snow. J Wildl Manage 71:22212229
McShea WJ, Koy K et al (2005) Finding a needle in the haystack: regional analysis of suitable Eld's deer (Cervus eldi) forest in Southeast Asia. Biol Conserv 125:101-111

Mortelliti A, Boitani L (2008) Inferring red squirrel (Sciurus vulgaris) absence with hair tubes surveys: a sampling protocol. Eur J Wildl Res 54:353-356

Nielsen CLR, Wakamiya SM et al (2008) Viability and patch occupancy of a swamp rabbit metapopulation at the northern edge of its distribution. Biol Conserv 141:1043-1054

Odell EA, Pusateri FM et al (2008) Estimation of occupied and unoccupied black-tailed prairie dog colony acreage in Colorado. $\mathrm{J}$ Wildl Manage 72:1311-1317

Onorato D, White C et al (2006) Detection of predator presence at elk mortality sites using mtDNA analysis of hair and scat samples. Wildl Soc Bull 34:815-820

Roger E, Laffan SW et al (2007) Habitat selection by the common wombat (Vombatus ursinus) in disturbed environments: Implications for the conservation of a 'common' species. Biol Conserv 137:437-449

Ruell EW, Crooks KR (2007) Evaluation of noninvasive genetic sampling methods for felid and canid populations. J Wildl Manage 71:1690-1694

Ruiz-Gonzalez A, Rubines J et al (2008) A non-invasive genetic method to identify the sympatric mustelids pine marten (Martes martes) and stone marten (Martes foina): preliminary distribution survey on the northern Iberian Peninsula. Eur J Wildl Res 54:253-261

Sargeant GA, Sovada MA et al (2005) Markov chain Monte Carlo estimation of species distributions: a case study of the swift fox in western Kansas. J Wildl Manage 69:483-497

Schauber EM, Scharine PD et al (2008) An artificial latrine log for swamp rabbit studies. J Wildl Manage 72:561-563

Smith DA, Ralls K et al (2005) Assessment of scat-detection dog surveys to determine kit fox distribution. Wildl Soc Bull 33:897-904

Steinmetz R, Garshelis DL (2008) Distinguishing Asiatic black bears and sun bears by claw marks on climbed trees. J Wildl Manage $72: 814-821$

Telesco RL, Van Manen FT et al (2007) Identifying sites for elk restoration in Arkansas. J Wildl Manage 71:1393-1403

Waltert M, Meyer B et al (2008) Foot surveys of large mammals in woodlands of western Tanzania. J Wildl Manage 72:603-610

Watts DE, Parker ID et al (2008) Distribution and abundance of endangered Florida key deer on outer islands. J Wildl Manage $72: 360-366$

Weller TJ (2008) Using occupancy estimation to assess the effectiveness of a regional multiple-species conservation plan: bats in the Pacific Northwest. Biol Conserv 141:2279-2289

Wintle BA, Kavanagh RP et al (2005) Estimating and dealing with detectability in occupancy surveys for forest owls and arboreal marsupials. J Wildl Manage 69:905-917

Zeng ZG, Skidmore AK et al (2008) Seasonal altitudinal movements of golden takin in the Qinling Mountains of China. J Wildl Manage 72:611-617

\section{References}

Birks JDS (2008) The polecat survey of Britain 2004-2006. A report on the polecat's distribution, status and conservation. The Vincent Wildlife Trust, London 
Birks J, Messenger J, Braithwaite T, Davison A, Brookes R, Strachan C (2004) Are scat surveys a reliable method for assessing distribution and population status of pine martens? In: Harrison DJ, Fuller AK, Proulx G (eds) Martens and fishers in humanaltered environments. Springer US, New York, pp 235-252

Bonesi L, Macdonald DW (2004) Critical evaluation of sign surveys as a way to estimate the relative abundance of American mink (Mustela vison). J Zool 262:65-72

Bukinski J, McArthur C (2000) Observer error in counts of macropod scats. Wild Res 27:277-282

Burnham E, Bender LC, Eiceman GA, Pierce KM, Prasad S (2008) Use of volatile organic components in scat to identify canid species. J Wildl Manage 72:792-797

Craik JCA (1997) Long-term effects of North American mink Mustela vison on seabirds in western Scotland. Bird Study 44: 303-309

Darling JA, Blum MJ (2007) DNA-based methods for monitoring invasive species: a review and prospectus. Biol Invas 9:751-765

Davison A, Birks JDS, Brookes RC, Braithwaite TC, Messenger JE (2002) On the origin of faeces: morphological versus molecular methods for surveying rare carnivores from their scats. J Zool 257:141-143

Dunstone N (1993) The mink. T \& AD Poyser Ltd, London

Fernández GJ, Corley JC, Capurro AF (1997) Identification of cougar and jaguar feces through bile acid chromatography. J Wildl Manage 61:506-510

Fraser E, Glass D, Hogg S (2005) The distribution of water voles in Caithness. Caithness Biodiversity Group

Garcia P, Ayres C, Mateos I (2009) Seasonal changes in American mink (Neovison vison) signs related to Eurasian otter (Lutra lutra) presence. Mammalia 73:253-256

Gibbs JP (2000) Monitoring populations. In: Boitani L, Fuller TK (eds) Research techniques in animal ecology, controversies and consequences. Columbia University Press, New York, p 422

Green R, Green J (1997) Otter survey of Scotland: 1991-1994. The Vincent Wildlife Trust, London

Hansen MM, Jacobsen L (1999) Identification of mustelid species: otter (Lutra lutra), American mink (Mustela vison) and polecat (Mustela putorius) by analysis of DNA from faecal samples. J Zool 247:177-181

Harrington LA (2007) The American mink, Mustela vison: its management and interactions with two native mustelids, the European polecat, M. putorius, and the Eurasian otter, Lutra lutra. DPhil thesis, University of Oxford, UK

Harrington LA, Macdonald DW (2008) Spatial and temporal relationships between invasive American mink and native European polecats in the southern United Kingdom. J Mammal 89:9911000

Harrington LA, Harrington AL, Macdonald DW (2008a) Estimating the relative abundance of American mink Mustela vison on lowland rivers: evaluation and comparison of two techniques. Eur J Wildl Res 54:79-87

Harrington LA, Harrington AL, Macdonald DW (2008b) Distinguishing the tracks of mink Mustela vison and polecat M. putorius. Eur J Wildl Res 54:367-371

Janečka JE, Jackson R, Yuquang Z, Diqiang L, Munkhtsog B, Buckley-Beason V, Murphy WJ (2008) Population monitoring of snow leopards using noninvasive collection of scat samples: a pilot study. Anim Conserv 11:401-411

Jefferies DJ (2003) The water vole and mink survey of Britain 1996-1998 with a history of the long-term changes in the status of both species and their causes. The Vincent Wildlife Trust, London
Johnson MK, Belden RC, Aldred DR (1984) Differentiating mountain lion and bobcat scats. J Wildl Manage 48:239-244

Kalz B, Jewgenow K, Fickel J (2006) Structure of an otter (Lutra lutra) population in Germany-results of DNA and hormone analyses from faecal samples. Mamm Biol 71:321-335

Kruuk H (2006) Otters. Ecology, behaviour and conservation. Oxford University Press, Oxford

Long RA, Donovan TM, Mackay P, Zielinski WJ, Buzas JS (2007) Effectiveness of scat detection dogs for detecting forest carnivores. J Wildl Manage 71:2007-2017

Macdonald DW, Harrington LA (2003) The American mink: the triumph and tragedy of adaptation out of context. NZ J Zool 30:421-441

Major M, Johnson MK, Davis WS, Kellogg TF (1980) Identifying scats by recovery of bile acids. J Wildl Manage 44:290-293

McKelvey KS, Kienast JV, Aubry KB, Koehler GM, Maletzke BT, Squires JR, Lindquist EL, Loch S, Schwartz MK (2006) DNA analysis of hair and scat collected along snow tracks to document the presence of Canada lynx. Wildl Soc Bull 34:451-455

Prugh LR, Ritland CE (2005) Molecular testing of observer identification of carnivore feces in the field. Wildl Soc Bull 33:189-194

Reed JE, Baker RJ, Ballard WB, Kelly BT (2004) Differentiating Mexican gray wolf and coyote scats using DNA analysis. Wildl Soc Bull 32:685-692

Reynolds JC, Short MJ, Leigh RJ (2004) Development of population control strategies for mink Mustela vison, using floating rafts as monitors and trap sites. Biol Conserv 120:533-543

RSPB (2002) The population status of birds in the UK. Birds of conservation concern: 2002-2007. RSPB, Sandy, Bedfordshire

Sidorovich VE (1999) How to identify mustelid tracks. Small Carniv Conserv 20:22-27

Smith DA, Ralls K, Hurt A, Adams B, Parker M, Davenport B, Smith MC, Maldonado JE (2003) Detection and accuracy rates of dogs trained to find scats of San Joaquin kit foxes (Vulpes macrotis mutica). Anim Conserv 6:339-346

Strachan R (1995) Mammal detective. Whittet Books, London

Strachan R (2007) National survey of otter Lutra lutra distribution in Scotland 2003-04. SNH Commissioned Report No. 211. SNH, Inverness

Strachan C, Jefferies DJ, Baretto GR, Macdonald DW, Strachan R (1998) The rapid impact of resident American mink on water voles: case studies in lowland England. In: Dunstone N, Gorman ML (eds) Behaviour and ecology of Riparian mammals. Cambridge University Press, Cambridge, pp 339-357

Wasser SK, Davenport B, Ramage ER, Hunt KE, Parker M, Clarke C, Stenhouse G (2004) Scat detection dogs in wildlife research and management: application to grizzly and black bears in the Yellowhead Ecosystem, Alberta, Canada. Can J Zool 82:475-492

Wilson DE, Reeder DM (eds) (2005) Mammal species of the world. A taxonomic and geographic reference, 3rd edn. John Hopkins University Press, Baltimore, Maryland

Yamaguchi N, Macdonald DW (2003) The burden of co-occupancy: intraspecific resource competition and spacing patterns in American mink, Mustela vison. J Mammal 84:1341-1355

Zielinski WJ, Kucera TE (1995) American marten, fisher, lynx and wolverine: survey methods for their detection. General Technical Report PSW-157. US Department of Agriculture Forest Service, Pacific Southwest Research Station, Berkeley, California, USA. (available at www.fs.fed.us/psw/publications/gtr-157)

Zuercher GL, Gipson PS, Stewart GC (2003) Identification of carnivore feces by local peoples and molecular analyses. Wildl Soc Bull 31:961-970 